\title{
PEMANFAATAN AUDIOVISUAL DALAM PENANGANAN DEPRESI PADA REMAJA
}

\author{
Lala $^{1^{*}}$, Renta Sianturi ${ }^{2}$, Mifta Chaerunisa ${ }^{3}$, Nola Friska Nur Anggreini ${ }^{4}$, Prita Lestari ${ }^{5}$, Reica Vina \\ Farida $^{6}$, Rizma Hilmayasari ${ }^{7}$, Seylin Ni'mah Amran ${ }^{8}$, Sovy Zul Pratywie ${ }^{9}$ \\ 1. Program Studi DIII Keperawatan, STIKES Mitra Keluarga, Bekasi-Indonesia \\ 2. Program Studi S1 Keperawatan, STIKES STIKes Mitra Keluarga, Bekasi-Indonesia \\ 3. Program Studi DIII Keperawatan, STIKES Mitra Keluarga, Bekasi-Indonesia \\ 4. Program Studi DIII Keperawatan, STIKES Mitra Keluarga, Bekasi-Indonesia \\ 5. Program Studi DIII Keperawatan, STIKES Mitra Keluarga, Bekasi-Indonesia \\ 6. Program Studi DIII Keperawatan, STIKES Mitra Keluarga, Bekasi-Indonesia \\ 7. Program Studi DIII Keperawatan, STIKES Mitra Keluarga, Bekasi-Indonesia \\ 8. Program Studi DIII Keperawatan, STIKES Mitra Keluarga, Bekasi-Indonesia \\ 9. Program Studi DIII Keperawatan, STIKES Mitra Keluarga, Bekasi-Indonesia
}

*Korespondensi: Lala | STIKes Mitra Keluarga | lala@gmail.com

\begin{abstract}
Abstrak
Pendahuluan: Depresi pada remaja merupakan masalah yang sangat penting karena akan menjadi masalah yang lebih lanjut pada remaja yang dapat menyebabkan peningkatan kecemasan, kesepian, gangguan tidur, bahkan menyebabkan bunuh diri. Pada sebuah penelitian menemukan bahwa 60,8\% mahasiswa merasa sangat cemas, 38,2\% merasa sangat tertekan sehingga sulit untuk berfungsi, dan 10,4\% serius menganggap bunuh diri. Penggunaan teknologi audiovisual menggunakan aplikasi telah terbukti dalam mengurangi tingkat depresi pada remaja.

Metode Penulis melakukan kajian literatur dengan pendekatan sederhana terhadap 13 artikel tentang pemanfaatan aplikasi audio visual dengan masalah depresi mental pada remaja dalam periode 2015-2020 dengan maksud untuk mengetahui keefektifan penggunaan teknologi bagi masalah depresi mental pada remaja

Hasil: Hasil yang didapat dalam penggunaan aplikasi audiovisual dalam mengurangi masalah depresi pada remaja metode ini mampu memunculkan ketertarikan remaja dalam mengetahui masalahnya dengan informasi yang disampaikan dapat berupa audio, video, dan audiovisual/ animasi dan mengurangi tingkat depresi pada remaja tersebut.

Kesimpulan: Masih kurangnya penelitian tentang penggunaan teknologi aplikasi audiovisual di indonesia menjadi tantangan bagi para peneliti selanjutnya, besarnya manfaat yang dibbuktikan dari penggunaan teknologi aplikasi audiovisual bagi remaja dengan masalah depresi mental diharapkan mampu meningkatkan keinginan perawat dalam mengadvokasi atau edukasi keluarga dan klien dalam penggunaan teknologi tersebut serta melakukan penelitian lebih lanjut di Indonesia.
\end{abstract}

Kata Kunci: Depresi mental, Remaja, Audio visual, Aplikasi.

Diterima 17 November 2020; Accepted 30 Desember 2020

\section{PENDAHULUAN}

Remaja, atau yang dikenal dengan istilah adolescere dalam Bahasa latin berarti to grow atau to grow maturity (Jahja, 2011). Badan Kesehatan Dunia World Health Organization (WHO, 2015) memberikan batasan mengenai siapa remaja secara konseptual. Dikemukakan oleh WHO, remaja ditandai dari tiga aspek yaitu biologis (meliputi pertumbuhan organ reproduksi sekunder hingga masa pubertas), psikologis (cara berpikir dan pengelolaan emosidari anak-anak menuju dewasa), dan yang selanjutnya ialah sosial ekonomi, remaja cenderung lebih mandiri dari anak-anak yang karakteristiknya bergantung total.

Remaja awal usia 11-13 tahun memiliki potensi depresi ringan ketimbang anak remaja usia 14-18 tahun. Permasalahan-permasalahan yang muncul sebagai pemicu terjadinya depresi pada remaja umumnya meliputi kurangnya rasa percaya diri terhadap penampilan fisik. Namun jika dilihat dari segi status sosial, remaja dengan status sosial ekonomi rendah memiliki potensi terkena depresi berat ketimbang mereka yang memiliki status sosial ekonomi tinggi (Pratt dan Brody, 2012). Gejala depresi yang muncul pada remaja meliputi perasaan sedih yang berkepanjangan, mengisolasi diri, lebih banyak melamun saat sedang dalam kelas. Tidak hanya itu, gangguan makan, gangguan pola tidur, sering merasa lelah, lesu atau kurang bertenaga, gangguan interaksi sosial, sulit konsentrasi dan sulit mengambil keputusan menjadi raga gejala depresi yang menyertai. Depresi pun dapat menyerang kepribadian dan sifat seorang remaja yang 
selanjutnya akan mudah merasa putus asa, tidak ada inisiatif, bahkan ketidaktertarikan dalam

Dalam perjalanan proses depresi yang disebabkan beberapa faktor, baik faktor genetik, biologi, lingkungan, dan faktor psikologis. Para peneliti terdahulu menemukan bahwa depresi melankolis, gangguan bipolar, dan depresi postpartum, berkaitan dengan peningkatan kadar sitoksin yang berkombinasi dengan penurunan sensitivitas kortisol (Brogan, 2014), Menurut data WHO (2016), secara umum terdapat sekitar 35 juta orang terkena depresi, 60 juta orang terkena bipolar, 21 juta terkena skizofrenia, serta 47,5 juta terkena demensia. Di Indonesia, dengan berbagai faktor biologis, psikologis dan sosial dengan keanekaragaman penduduk maka jumlah kasus gangguan jiwa terus bertambah yang berdampak pada penambahan beban negara dan penurunan produktivitas manusia untuk jangka panjang. Data Riskesdas 2018 menunjukkan prevalensi ganggunan mental emosional yang ditunjukkan dengan gejala-gejala depresi dan kecemasan untuk usia 15 tahun ke atas mencapai sekitar $6.1 \%$ dari jumlah penduduk Indonesia. Menurut National Alliance of Mental Illness (NAMI) berdasarkan hasil sensus penduduk Amerika Serikat tahun 2013, di perkirakan 61.5 juta penduduk yang berusia lebih dari 18 tahun mengalami gangguan jiwa, 13,6 juta diantaranya mengalami gangguan jiwa berat seperti skizofrenia, gangguan bipolar.

Sistem Informasi Kesehatan adalah seperangkat tatanan yang meliputi data, informasi, indikator, prosedur, perangkat, teknologi, dan sumber daya manusia yang saling berkaitan dan dikelola secara terpadu untuk mengarahkan tindakan atau keputusan yang berguna dalam mendukung pembangunan kesehatan (Menteri Kesehatan Republik Indonesia), berbeda dengan yang dianut oleh WHO, Audio-Visual (Avs) dalam mempelajari ilmu keperawatan seperti penggunaan You tube dan aplikasi Web 2.0 lainnya seperti "facebook", "Myspace" (Hansen \& Erdley, 2009). Youtube disini digunakan sebagai sarana untuk belajar dalam bentuk media pembelajaran audio visual jenis video.

Dalam undang-undang kesehatan no. 36/ 2009, disebutkan bahwa teknologi dalam bidang kesehatan merupakan bagian integral dari sumber daya kesehatan yang berfungsi dalam peningkatan status kesehatan pasien, definisi dari teknologi kesehatan adalah segala bentuk alat dan/atau metode yang ditujukan untuk membantu menegakkan diagnosa, pencegahan, dan penanganan permasalahan kesehatan manusia (Kemenkes, 2009).

\section{METODE}

Metode penelusuran yang digunakan dalam penulisan artikel ini melalui pendekatan sederhana (simplified approach) berdasarkan tema tertentu yang telah ditentukan oleh penulis. Pencarian artikel menggunakan beberapa database dan website pencari meliputi Google Scholar, ScienceDirect dan PubMed. Tahun publikasi dibatasi antara tahun 2015-2020 menggunakan kata kunci "Utilization", "Audio Visual", "Mobile App", "Depression", "Mental Disorder", "Mental stress", "Mental Health", "adolescents" dengan kriteria inklusi meliputi: artikeltentang pemanfaatan audiovisual dan aplikasi smarthphone dengan masalah depresi mental pada remaja, artikel dalam 5 tahun terakhir (2015-2020). Sementara kriteria eksklusi yang dipergunakan adalah artikel teknologi atau aplikasi smarthphone tanpa depresi mental, artikel bukan berbahasa indonesia dan inggris, artikel yang tidak spesifik penggunaan teknologi dengan masalah depresi mental pada remaja. Artikel yang di dapat sebanyak 14 buah diperkecil menjadi 13 artikel yang sesuai dengan tujuan penulisan artikel.

\section{HASIL}

Depresi pada remaja menjadi salah satu gangguan psikologis dimana penderitanya merasakan sedih berkepanjangan dan kehilangan semangat hidup, yang dapat mempengaruhi kondisi fisik seperti masalah pencernaan dan nyeri akut. Beberapa penelitian telah membuktikan penggunaan alat bantu seperti teknologi dalam membantu mengurangi atau mencegah depresi mental pada usia remaja. Dalam studi literatur ini, penulis (kelompok) mengumpulkan 13 artikel yang terkait dengan pemanfaatan dan penggunaaan teknologi dalam mencegah depresi mental pada remaja. Artikel yang diambil dari beberapa sumber jurnal dalam 5 periode tahun terakhir 2015-2020 hasil yang didapat adalah:

\begin{tabular}{|l|l|l|}
\hline \multicolumn{2}{|c|}{ Judul Jurnal } & \multicolumn{2}{|c|}{ Hasil } \\
\hline $\begin{array}{l}\text { 1) } \\
\text { mental }\end{array}$ & $\begin{array}{l}\text { Internet-delivered } \\
\text { health treatment }\end{array}$ & $\begin{array}{l}\text { Mengevaluasi kegunaan dan desain responsif dari sistem perawatan yang } \\
\text { disampaikan melalui Internet. Kegunaan dan prinsip desain universal dalam evaluasi }\end{array}$ \\
\hline
\end{tabular}


systems in Scandinavia $-A$ usability evaluation

system perawatan yang disalurkan melalui Internet. Temuan ini menunjukkan bahwa meskipun dengan hasil pengobatan yang baik dan efek klinis yang terbukti, sistem secara umum memiliki beberapa masalah terkait kegunaan, desain universal, dan teknologi yang ketinggalan zaman. Berdasarkan temuan, kami mengusulkan bahwa harus ada pedoman yang ditetapkan untuk menguji kegunaan dan teknologi system perawatan yang disalurkan melalui Internet

2) IntelliCare: An Eclectic, Skills Based App Suite for the Treatment of Depression and Anxiety.

3) Jamaican adolescents receptiveness to digital mental health services: A cross- sectional survey from rural and urban communities

4) Depression in Adolescents with ASD: A Pilot RCT of a Group Intervention

5) The Mindfulness App Trial for Weight, WeightRelated Behaviors, and Stress in University Students

6) Individually tailoredinternet-

based cognitive behavioural therapy foryoung adults with anxiety disorders: A pilot effectiveness study
Studi ini mendukung kerangka kerja Intelli Care dalam menyediakan rangkaian aplikasi yang berfokus pada keterampilan yang dapat sering digunakan untuk mengurangi gejala depresi dan kecemasan. Sistem Intelli Care bersifat elemental, memungkinkan aplikasi individu menjadi digunakan atau tidak digunakan berdasarkan keefektifan dan kegunaannya, dan bersifat eklektik, memandang strategi pengobatan sebagai elemen yang dapat dilakukan diterapkan sesuai kebutuhan dari pada mengikuti model teoretis tunggal dan menyeluruh.

$>90 \%$ sampel memiliki akses ke smartphone, $78 \%$ mengharapkan solusi digital dapat bermanfaat bagi remaja dengan gejala gangguan mental, dan $56 \%$ tertarik menggunakan aplikasi kesehatan mental untuk memantau kesehatan mental mereka sendiri. Stigma, rasa malu, dan rasa malu adalah hambatan utama untuk mencari bantuan dan bantuan profesional formal hanya disukai untuk kondisi yang lebih parah seperti psikosis dan penyalahgunaan zat.

Depresi berpotensi mengancam nyawa gangguan afektif yang sangat umum pada individu dengan gangguan spektrum autisme (ASD). Penelitian ini bertujuan untuk mengevaluasi kelayakan, penerimaan dan kemanjuran awal dari intervensi perilaku kognitif untuk depresi pada remaja dengan ASD. Partisipan secara acak ditugaskan ke kelompok intervensi, atau kontrol daftar tunggu kelompok. Meskipun perekrutan sangat sulit, kehadirannya menguntungkan dan atrisi rendah, dan peserta melaporkan puas dengan program tersebut. Tidak efek pengobatan yang signifikan terungkap pada Beck Inventaris Depresi atau Kuesioner Peraturan Emosi. Namun meskipun ukuran sampel kecil $(\mathrm{n}=20)$, ada efek pengobatan yang sedang tren yang diukur dengan Depression Anxiety Stress Scale: Depression Subscale. Keterbatasan dan bidang penelitian masa depan dibahas.

Baik grup aplikasi mindfulness maupun grup e-diary tidak mengalami penurunan berat badan dan tidak ada perbedaan antara grup saat tindak lanjut. Grup aplikasi mindfulness memiliki tingkat stres yang jauh lebih rendah $(\mathrm{P}=$. 02) (khusus pengikut), makan emosional lebih rendah $(\mathrm{P}=.02)$, dan makan yang tidak terkontrol $(\mathrm{P}=.02)$ serta perhatian yang lebih tinggi $(\mathrm{P} . \leq$. 001) dan level ME secara keseluruhan ( $\mathrm{P} . \leq$. 001). Kelompok e-diary memiliki tingkat aktivitas sedang yang setara metaboliknya lebih tinggi ( P. $\leq .01$ ). Namun, ukuran efeknya kecil. Kepatuhan rutin pada latihan kesadaran di aplikasi rendah di grup. Mayoritas siswa (94\%) menyukai aplikasi dan menganggapnya dapat diterima. Dibandingkan dengan latihan lain, meditasi yang dilaporkan paling membantu adalah latihan pernapasan pendek dengan mengamati napas (39,4\% [13/33] lebih menyukainya).

Tujuan dari penelitian ini adalah untuk menyelidiki efek dari CBT yang dikelola internet yang Disesuaikan untuk dewasa komorbiditas dalam perawatan rutin. Beck Anxiety Inventory, adalah d = 1,50, efek dalam kelompok pada ukuran hasil sekunder, Montgomery Åsberg Depression Rating Scale-SelfRated, Hasil Klinis dalam Evaluasi Rutin dan Kualitas Hidup Persediaan menunjukkan peningkatan yang besar. Perawatan berbasis internet yang disesuaikan dapat menjadi pendekatan dalam pengobatan gejala kecemasan dan gejala depresi komorbid dalam perawatan remaja.

Hasil studi ini akan berkontribusi pada penelitian yang berkembang tentang intervensi yang dilakukan melalui Internet. Hasil yang diharapkan dapat berdampak besar pada pencegahan gangguan mental dan kemungkinan konsekuensi negatif pada populasi berisiko, seperti mahasiswa
7) An Internet based intervention for improving resilience and coping strategies in University students: Study protocol for a randomized 


\begin{tabular}{|c|c|}
\hline ntrolled trial & \\
\hline $\begin{array}{l}\text { 8) Effectiveness of an } \\
\text { Internet-and App-Based } \\
\text { Intervention for College } \\
\text { Students With Elevated } \\
\text { Stress: Randomized } \\
\text { ControlledTrial }\end{array}$ & $\begin{array}{l}\text { Intervensi berbasis internet dan seluler dapat menjadi pendekatan yang efektif dan } \\
\text { hemat biaya untuk mengurangi konsekuensi stres terkait perguruan tinggi dan } \\
\text { berpotensi menarik siswa dengan depresi yang relevan secara klinis yang tidak akan } \\
\text { mencari bantuan. }\end{array}$ \\
\hline $\begin{array}{l}\text { 9) Feasibility of an Online } \\
\text { Mindfulness Program for } \\
\text { Stress Management-A } \\
\text { Randomized, Controlled } \\
\text { Trial }\end{array}$ & $\begin{array}{l}\text { Studi ini menunjukkan program ISM } 8 \text { minggu bisa mengurangi stres secara layak } \\
\text { dan efektif. Manfaat itu dipertahankan hingga minggu ke } 12 \text { untuk sebagian besar } \\
\text { berpendidikan populasi yang dipilih sendiri oleh wanita dan ahli komputer. Meskipun } \\
\text { tingkat penyelesaian peserta rendah, file besarnya peningkatan signifikan bagi mereka } \\
\text { yang menyelesaikan program online. Studi ini memberikan dukungan untuk program } \\
\text { manajemen stres online dapat diakses publik dan tidak mahal }\end{array}$ \\
\hline $\begin{array}{l}\text { 10) Efficacy of the } \\
\text { Mindfulness Meditation } \\
\text { Mobile App "Calm" to } \\
\text { Reduce Stress Among } \\
\text { College Students: } \\
\text { Randomized Controlled } \\
\text { Trial }\end{array}$ & $\begin{array}{l}\text { Mayoritas siswa dalam kelompok intervensi melaporkan bahwa Calm } \\
\text { membantumengurangi stres dan menyatakan } \\
\text { menggunakan Calm di masa mendatang. Mayoritas puas menggunakan Calm dan } \\
\text { cenderung merekomendasikannya kepada mahasiswa lain. Kelompok intervensi } \\
\text { berpartisipasi dalam meditasi selama rata- rata } 38 \text { menit / minggu selama intervensi } \\
\text { dan } 20 \text { menit / minggu selama tindak lanjut. Ketenangan adalah modalitas yang } \\
\text { efektif untuk menyampaikan meditasi. }\end{array}$ \\
\hline $\begin{array}{l}\text { 11) The Efficacy of } \\
\text { Internet-Based } \\
\text { Mindfulness Training and } \\
\text { Cognitive-Behavioral } \\
\text { Training With Telephone } \\
\text { Support in the } \\
\text { Enhancement of Mental } \\
\text { Health Among College } \\
\text { Students and Young } \\
\text { Working Adults: } \\
\text { Randomized Controlled } \\
\text { Trial }\end{array}$ & $\begin{array}{l}\text { Penelitian menunjukkan bahwa terdapat pengaruh waktu yang signifikan }(\mathrm{P}<.001) \text {. } \\
\text { Ini meningkat secara signifikan dari dasar ke pasca program di iMIND dan iCBT } \\
\text { (perbedaan rata-rata }=-0.46,95 \% \text { CI }-0.59 \text { menjadi }-0.33, \mathrm{P}<.001 \text { ) dan } \\
\text { dipertahankan pada tindak lanjut } 3 \text { bulan (perbedaan rata-rata }=-0,25,95 \% \mathrm{CI}-0,41 \\
\text { hingga }-0,09, \mathrm{P}=.001) \text {. MHI tidak berbeda secara signifikan antara iMIND dan iCBT } \\
\text { (perbedaan rata-rata }=0,08,95 \% \mathrm{CI}-0,05 \text { hingga } 0,22, \mathrm{P}=.22 \text { ). Pengaruh interaksi } \\
\text { waktu } \mathrm{x} \text { kondisi }(\mathrm{P}=.18 \text { ) juga tidak signifikan, yang menunjukkan bahwa iMIND } \\
\text { dan iCBT menunjukkan peningkatan yang serupa dari waktu ke waktu. }\end{array}$ \\
\hline $\begin{array}{l}\text { 12) Internet-based guided } \\
\text { self-help for university } \\
\text { students with anxiety, } \\
\text { depression and stress: A } \\
\text { randomized } \\
\text { clinical trial }\end{array}$ & $\begin{array}{l}\text { Studi ini menyelidiki kemanjuran program bantuan mandiri online untuk mahasiswa } \\
\text { dengan depresi, kecemasan, dan stres. Temuan utama dari penelitian ini adalah } \\
\text { partisipan yang memiliki akses untuk program bantuan mandiri terpandu meningkat } \\
\text { secara signifikan dengan sehubungan dengan tingkat kecemasan, depresi dan stres } \\
\text { yang dilaporkan sendiri, dibandingkan dengan peserta dalam kondisi akses tertunda. } \\
\text { Pada awal penelitian, peserta mendukung kecemasan, depresi, dan gejala stres di } \\
\text { ujung atas dari kisaran sedang. Setelah menyelesaikan modul program inti, disetujui } \\
\text { oleh peserta gejala kecemasan, depresi, dan stres ringan tingkat keparahan, } \\
\text { menunjukkan peningkatan yang signifikan dalam hal ini gejala. Lebih lanjut, peserta } \\
\text { yang menanggapi kuesioner tindak lanjut enam bulan menunjukkan bahwa mereka } \\
\text { mempertahankan manfaat menyelesaikan program berbasis online dengan gejala di } \\
\text { ujung bawah dari rentang keparahan ringan hingga kisaran normal kecemasan, } \\
\text { depresi dan stres }\end{array}$ \\
\hline $\begin{array}{l}\text { 13) Computer-Based and } \\
\text { Online Therapy for } \\
\text { Depression and Anxiety in } \\
\text { Children and Adolescents }\end{array}$ & $\begin{array}{l}\text { Semakin banyak bukti yang mendukung penggunaan komputer dan Internet dalam } \\
\text { penyediaan intervensi untuk depresi dan kecemasan pada anak-anak dan remaja. } \\
\text { Sejumlah program terbukti efektif dalam RCT yang dirancang dengan baik. Replikasi } \\
\text { dan studi tindak lanjut jangka panjang diperlukan untuk mengkonfirmasi hasil. }\end{array}$ \\
\hline
\end{tabular}

Dalam pelaksanaan yang didasarkan literatur sumber, diketahui bahwa seluruh artikel yang direview menerangkan salah satu keuntungan dari pengguanaan teknologi dapat mencegah depresi mental yang terjadi pada remaja. Perawatan berbasis internet yang disesuaikan dapat menjadi pendekatan dalam pengobatan gejala kecemasan dan gejala depresi dalam perawatan remaja. Intervensi berbasis internet dan seluler dapat menjadi pendekatan yang efektif dan hemat biaya untuk mengurangi konsekuensi stres terkait perguruan tinggi dan berpotensi menarik siswa dengan depresi yang relevan secara klinis yang tidak akan mencari bantuan. Teknologi yang digunakan pada klien dengan depresi mental dapat diintervensikan 
dengan menggunakan audiovisual Berdasarkan hasil yang didapatkan data diatas bahwa teknologi yang paling efektif adalah Efficancy of the Mindfulness Meditation Mobile App "Calm" to Reduce Stress Among College Students: Randomized Controlled Trial dengan hasil Mayoritas siswa dalam kelompok intervensi melaporkan bahwa Calm membantu mengurangi stres dan menyatakan bahwa mereka akan menggunakan Calm di masa mendatang. Mayoritas puas menggunakan Calm dan cenderung merekomendasikannya kepada mahasiswa lain. Kelompok intervensi berpartisipasi dalam meditasi rata-rata 38 menit/ minggu selama intervensi dan 20 menit/ minggu selama tindak lanjut. Ukuran efek pada intervensi ini berkisar dari sedang $(0,59)$ hingga besar $(1,24)$ di semua hasil kelompok intervensi.

\section{PEMBAHASAN}

Audiovisual dapat memberikan kontribusi berarti dalam perubahan perilaku termasuk dalam hal ini aspek kognitif dan psikologi individu. Kelebihan yang didapat dari penggunaan audio visual untuk remaja yang mengalami depresi yaitu di antaranya metode ini mampu memunculkan ketertarikan klien dalam mengetahui masalahnya, karena metode ini dibuat dengan informasi yang disampaikan dapat berupa audio, video, dan audiovisual/ animasi yang bisa memberikan gambaran terkait kondisi yang mereka alami dan rasakan secara nyata dan harapan-harapan masa depannya ketika ia mampu mengatasi depresinya. Dari metode tersebut individu bisa mendapatkan informasi tentang memahami pentingnya pengobatan dan terapi yang tepat dan individu bisa akan lebih kooperatif dengan pengobatan yang dilakukan serta dengan memberikan informasi tersebut, diharapkan individu akan lebih kooperatif dengan pengobatan yang akan dilakukan serta mampu beradaptasi dengan efek samping dari pengobatan yang diberikan. Pemberian psikoterapi berupa teknik-teknik yang dapat menurunkan atau mengurangi depresi yang dialami klien, mulai dari tingkat ringan sampai dengan sedang. Dengan pemberian informasi melalui audio visual tentang psikoterapi yang dilakukan diharapkan individu mampu untuk mengidentifikasi hal-hal negatif yang muncul yang dapat menyebabkan depresi.

Kekurangan yang muncul dari penggunaan audio visual dengan masalah depresi mental terutama pada remaja antara lain: penggunaan aplikasi berbasis audiovisual tidak semua kalangan bisa menggunakan (seperti gangguan pendengaran atau tuna rungu) karena. Audio visual yang ditampilkan (animasi) tidak semua kalangan yang berminat karena mayoritas remaja tidak menyukai konten animasi pada audio visual tersebut, dan Akses data base audio visual memiliki harga yang mahal dan layanan terbatas di beberapa wilayah dalam mengaksesnya (seperti smartphone, laptop, tablet, computer dan media lainnya), dengan kondisi ekonomi yang rendah tidak dapat mengaplikasikan dan memanfaatkannya. Penggunaan audio visual secara berlebihan memicu kecanduan terhadap pengguna karena klien merasa terlalu nyaman dan menyukai, hal ini menimbulkan dampak interaksi sosial terhadap klien dan tidak fokus terhadap lingkungan sekitarnya, sehingga timbul efek kecanduan, dan merugikan kesehatan tubuh seperti halusinasi yang berlebihan.

Terdapat beberapa hal yang harus diperhatikan terkait kemungkinan diimplementasikannya audio visual dengan masalah depresi mental terutama pada remaja, antara lain: (1) menstabilkan harga dan peralatan yang memadai sehingga mensosialisasikan dengan mudah (2) peningkatan koping dari klien (proses mengurangi rasa kecanduan klien) (3) edukasi kesehatan yang mendukung pelaksanaan penerapan tersebut (4) sumber daya manusia terutama remaja yang berkualitas (bijak dalam menggunakan tekonologi pendamping) (5) kondisi sumber daya teknologi yang aman terhadap klien untuk diimplementasikan dalam kehidupan sehari-hari.

\section{KESIMPULAN}

Teknologi menggunakan aplikasi berbasis audiovisual merupakan suatu teknologi yang tepat untuk diimplementasikan sebagai pelayanan kesehatan bagi klien remaja dengan masalah depresi mental dengan kebutuhan khusus yang membutuhkan bantuan di situasi tertentu. Peningkatan jumlah remaja di indonesia yang semakin bertambah setiap tahunnya dapat menjadi faktor pendukung utama pentingnya implementasi teknologi pendamping pada kegiatan sehari-harinya. Remaja dengan masalah depresi mental yang memiliki tingkatan stres akan mengalami ketidakmampuan dalam melakukan kegiatan sehari-hari tanpa dukungan dari orang sekitar, ketidaproduktifan ini dapat berakibat pada munculnya gesekan bio-psiko sosio-kultural antara klien dengan keluarga maupun sosial. Hasil studi literatur terhadap 13 artikel yang dilakukan penulis menunjukan bahwa pemanfaatan dan penggunaaan teknologi dalam mencegah depresi mental pada remaja, Kelebihan lain adalah dari penggunaan audio visual untuk remaja yang mengalami 
depresi yaitu di antaranya metode ini mampu memunculkan ketertarikan klien dalam mengetahui masalahnya, karena metode ini dibuat dengan informasi yang disampaikan dapat berupa audio, video, dan audiovisual/ animasi yang bisa memberikan gambaran terkait kondisi yang mereka alami dan rasakan secara nyata dan harapan-harapan masa depannya ketika ia mampu mengatasi depresinya. Selain efek positif, didapatkan beberapa efek negatif atau kekurangan dari pengaplikasian teknologi pada klien, antara lain: Penggunaan aplikasi berbasis audio visual tidak semua kalangan bisa menggunakan (seperti gangguan pendengaran atau tuna rungu) karena Audio visual yang ditampilkan (animasi) tidak semua kalangan yang berminat karena mayoritas remaja tidak menyukai konten animasi pada audio visual tersebut, dan Akses data base audio visual memiliki harga yang mahal dan layanan terbatas di beberapa wilayah dalam mengaksesnya (seperti smartphone, laptop, tablet, computer dan media lainnya), dengan kondisi ekonomi yang rendah tidak dapat mengaplikasikan dan memanfaatkannya.

Masih kurangnya penelitian tentang penggunaan teknologi aplikasi audiovisual di indonesia menjadi tantangan bagi para peneliti selanjutnya, besarnya manfaat yang dibbuktikan dari penggunaan teknologi aplikasi audiovisual bagi remaja dengan masalah depresi mental diharapkan mampu meningkatkan keinginan perawat dalam mengadvokasi atau edukasi keluarga dan klien dalam penggunaan teknologi tersebut serta melakukan penelitian lebih lanjut di Indonesia.

\section{UCAPAN TERIMA KASIH}

Penulis bersyukur selama penulisan artikel banyak mendapatkan bantuan moril dan materil dari rekanrekan angkatan dan staf dosen di institusi tempat penulis bekerja.

\section{REFERENSI}

Chambers, S. R. (2009). Undang-Undang Republik Indonesia Nomor 36 Tahun 2009 Tentang Kesehatan.

Day, V., McGrath, P. J., \& Wojtowicz, M. (2013). Internet-based guided self-help for university students with anxiety, depression and stress: A randomized controlled clinical trial. Behaviour Research and Therapy, 51(7), 344-351. https://doi.org/10.1016/j.brat.2013.03.003

Desi, D., Felita, A., \& Kinasih, A. (2020). Gejala Depresi Pada Remaja Di Sekolah Menengah Atas. Care : Jurnal Ilmiah Ilmu Kesehatan, 8(1), 30. https://doi.org/10.33366/jc.v8i1.1144

Harrer, M., Adam, S. H., Fleischmann, R. J., Baumeister, H., Auerbach, R., Bruffaerts, R., Cuijpers, P., Kessler, R. C., Berking, M., Lehr, D., \& Ebert, D. D. (2018). Effectiveness of an internet- and appbased intervention for college students with elevated stress: Randomized controlled trial. Journal of Medical Internet Research, 20(4), 1-16. https://doi.org/10.2196/jmir.9293

Herrero, R., Mira, A., Cormo, G., Etchemendy, E., Baños, R., García-Palacios, A., Ebert, D. D., Franke, M., Berger, T., Schaub, M. P., Görlich, D., Jacobi, C., \& Botella, C. (2019). An Internet based intervention for improving resilience and coping strategies in university students: Study protocol for a randomized controlled trial. Internet Interventions, 16(December 2017), 43-51. https://doi.org/10.1016/j.invent.2018.03.005

Huberty, J., Green, J., Glissmann, C., Larkey, L., Puzia, M., \& Lee, C. (2019). Efficacy of the mindfulness meditation mobile app "calm" to reduce stress among college students: Randomized controlled trial. Journal of Medical Internet Research, 21(6). https://doi.org/10.2196/14273

Lyzwinski, L. N., Caffery, L., Bambling, M., \& Edirippulige, S. (2019). The mindfulness app trial for weight, weight-related behaviors, and stress in university students: randomized controlled trial. Journal of Medical Internet Research, 21(4), 1-19. https://doi.org/10.2196/12210

Mak, W. W., Chio, F. H., Chan, A. T., Lui, W. W., \& Wu, E. K. (2017). The efficacy of internet-based mindfulness training and cognitive-behavioral training with telephone support in the enhancement of mental health among college students and young working adults: Randomized controlled trial. Journal of Medical Internet Research, 19(3). https://doi.org/10.2196/jmir.6737

Maloney, C. A., Abel, W. D., \& McLeod, H. J. (2020). Jamaican adolescents' receptiveness to digital mental health services: A cross-sectional survey from rural and urban communities. Internet Interventions, 21(May), 100325. https://doi.org/10.1016/j.invent.2020.100325

Mohr, D. C., Tomasino, K. N., Lattie, E. G., Palac, H. L., Kwasny, M. J., Weingardt, K., Karr, C. J., Kaiser, S. M., Rossom, R. C., Bardsley, L. R., Caccamo, L., Stiles-Shields, C., \& Schueller, S. M. (2017). Intellicare: An eclectic, skills-based app suite for the treatment of depression and anxiety. Journal of Medical Internet Research, 19(1), 1-14. https://doi.org/10.2196/jmir.6645 
Morledge, T. J., Allexandre, D., Fox, E., Fu, A. Z., Higashi, M. K., Kruzikas, D. T., Pham, S. V., \& Reese, P. R. (2013). Feasibility of an online mindfulness program for stress management - A randomized, controlled trial. Annals of Behavioral Medicine, 46(2), 137-148. https://doi.org/10.1007/s12160-0139490-x

Santomauro, D., Sheffield, J., \& Sofronoff, K. (2016). Depression in Adolescents with ASD: A Pilot RCT of a Group Intervention. Journal of Autism and Developmental Disorders, 46(2), 572-588. https://doi.org/10.1007/s10803-015-2605-4

Silfvernagel, K., Wassermann, C., \& Andersson, G. (2017). Individually tailored internet-based cognitive behavioural therapy for young adults with anxiety disorders: A pilot effectiveness study. Internet Interventions, 8, 48-52. https://doi.org/10.1016/j.invent.2017.03.002

Stasiak, K., Fleming, T., Lucassen, M. F. G., Shepherd, M. J., Whittaker, R., \& Merry, S. N. (2016). Computer-Based and Online Therapy for Depression and Anxiety in Children and Adolescents. Journal of Child and Adolescent Psychopharmacology, 26(3), 235-245. https://doi.org/10.1089/cap.2015.0029

Yogarajah, A., Kenter, R., Lamo, Y., Kaldo, V., \& Nordgreen, T. (2020). Internet-delivered mental health treatment systems in Scandinavia - A usability evaluation. Internet Interventions, 20(October 2019), 100314.https://doi.org/10.1016/j.invent.2020.100314 